\title{
Effects on egg production and quality of supplementing drinking water with calcium and magnesium
}

\author{
X.J. Yi ${ }^{1}$, A. Rehman ${ }^{\# 3}$, R.W. Akhtar ${ }^{3}$, A. Abbas ${ }^{3}$, K. Hussain ${ }^{3}$, R. Yasin ${ }^{3}$, H.M. Ishaq ${ }^{3}$, R.Z. \\ Abbas ${ }^{4}$, M.A. Raza ${ }^{3}$, H.S. Hu ${ }^{\# 1,2} \&$ G. $\mathrm{Li}^{2}$ \\ ${ }^{1}$ College of Agriculture, Department of Veterinary Science, Ningxia University, Ningxia Hui Autonomous Region \\ Yinchuan, China \\ ${ }^{2}$ Ningxia Xiaoming Agriculture and Husbandry Co. Ltd., Jinfeng District Yinchuan, 750011 China \\ ${ }^{3}$ Department of Veterinary and Animal Sciences, Muhammad Nawaz Sharif University of Agriculture Multan, Pakistan \\ ${ }^{4}$ Department of Parasitology, University of Agriculture Faisalabad, Pakistan
}

(Received 16 March 2021; Accepted 7 July 2021; Published 5 August 2021)

Copyright resides with the authors in terms of the Creative Commons Attribution 4.0 South African Licence.
See: http://creativecommons.org/licenses/by/4.0/za
$\begin{gathered}\text { Condition of use: The user may copy, distribute, transmit and adapt the work, but must recognise the authors and the South African } \\ \text { Journal of Animal Science. }\end{gathered}$

\begin{abstract}
This study was conducted to appraise the effects on egg quality and production performance of laying hens when drinking water was supplemented with calcium $(\mathrm{Ca})$ and magnesium $(\mathrm{Mg})$. A total of $384(64-$ week-old) Hy-line Brown laying hens were assigned at random to four treatments, which consisted of CON: unsupplemented drinking water; T1: drinking water $+2 \mathrm{mg} / \mathrm{L} \mathrm{Ca}+250 \mathrm{mg} / \mathrm{L} \mathrm{Mg}$; T2: drinking water $+4 \mathrm{mg} / \mathrm{L}$ $\mathrm{Ca}+510 \mathrm{mg} / \mathrm{L} \mathrm{Mg} / 10 \mathrm{~L}$; and T3: drinking water $+5 \mathrm{mg} / \mathrm{L} \mathrm{Ca}$ and $760 \mathrm{mg} / \mathrm{L} \mathrm{Mg}$. The experiment lasted six weeks. Water intake increased linearly in week 1 with the rising levels of $\mathrm{Ca}$ and $\mathrm{Mg}$ in the drinking water. Increasing the $\mathrm{Ca}$ and $\mathrm{Mg}$ levels improved eggshell strength (week $2(P=0.01)$, week $5(P=0.01)$, and week $6(P=0.03)$, and eggshell thickness (week 6) $(P=0.02)$ and reduced the rate at which eggs were broken (week 4) $(P=0.01)$. The supplemental $\mathrm{Ca}$ and $\mathrm{Mg}$ did not affect egg production, egg weight, Haugh unit, albumen height, eggshell colour, and yolk colour compared with CON. Nor did they influence the Haugh unit and albumen height after storing for 1, 5, 10 and 15 days. In conclusion, adding $\mathrm{Ca}$ and $\mathrm{Mg}$ to the drinking water increased the thickness and strength of the eggshells.
\end{abstract}

Keywords: eggshell, laying hens, minerals, poultry, water quality,

\#Corresponding Author: Atif1632@hotmail.com

\section{Introduction}

Water is important in many body functions in laying hens, including digestion, absorption, maintenance of ionic balance, excretion of waste materials, provision of media to transport nutrients, heat regulation and metabolism of nutrients (Schlink et al., 2010). Poor water quality can affect hen performance negatively, even when a well-balanced diet is supplied (Chung et al., 2020). High levels of dissolved minerals in water may have negative effects on poultry performance and health (Leeson \& Summers, 2008). For example, Ca is the major mineral in eggshells and bones (Whitehead, 2004), but excess dietary Ca can cause poor absorption of many essential minerals (Cufadar et al., 2011). But-high contents of $\mathrm{Ca}$ and $\mathrm{Mg}$ in water are known to reduce livestock performance. In addition, prolonged exposure to water that is high in $\mathrm{Mg}$ might reduce available $\mathrm{Ca}$ in body pools, which could affect eggshell and bone quality (Yenice et al., 2015). Ariyamuni (2015) demonstrated that $\mathrm{pH}$ (8.2) of water affected hen production negatively. But the effects on poultry performance, including laying hens, of high levels of minerals in the water are not well documented. Thus, there is a need to conduct studies that reveal the effects of mineral supplementation in water on poultry performance. But there are apparently few established guidelines to assess the quality of drinking water that are based on experimentation on poultry (Blake et al., 2019). Those that do exist are based on human standards and on recommendations for other livestock species. However, the use of human standards to evaluate animal drinking water may be inappropriate, since animals can tolerate higher levels of minerals and their ability to endure dissolved substances may be different from that of human beings (Youssef et al., 2009). Because of the dearth of scientific information on the mineral effects of water on egg quality and production, this study was planned to fill these knowledge gaps in laying hen nutrition. Thus, 
supplementation of $\mathrm{Ca}$ and $\mathrm{Mg}$ was hypothesized to affect the egg quality and production performance of hens. In this study, $\mathrm{Ca}$ and $\mathrm{Mg}$ were supplied in drinking water instead of in feed because water is consumed at a rate that is 1.6 - 2 times higher than feed. In addition, water is used to transport nutrients and for chemical and enzymatic reactions, which could make it a better carrier for the supplement. Therefore, the effects on production performance and egg quality of various levels of $\mathrm{Ca}$ and $\mathrm{Mg}$ in drinking water were assessed. Egg weight, eggshell crack, yolk colour, yolk height, albumen height, and Haugh unit were investigated. The study provided insights into the supplementation of $\mathrm{Ca}$ and $\mathrm{Mg}$ to improve the egg quality of hens, which could be used as a reference for the feed management of other birds.

\section{Materials and Methods}

Calcium and $\mathrm{Mg}$ were provided by a commercial company (Yinchuan, Ningxia). These minerals had been extracted from deep ocean water pumped from a depth of $510 \mathrm{~m}$ in the South China Sea, according to the supplier. A total of 384 (62-week-old) Hy-line Brown laying hens were used in the six-week feeding trial. The birds were randomly divided into four treatments with eight replications of twelve birds. Hens were housed in individual cages in a windowless and environmentally controlled house with stable temperature $\left(21^{\circ} \mathrm{C}\right)$ and a light regime was set at 16 hours light and 8 hours dark. Birds were given ad-libitum access to feed and water throughout the trial. The four treatments consisted of CON, drinking water; T1, drinking water $+2 \mathrm{mg} / \mathrm{L} \mathrm{Ca}+250 \mathrm{mg} / \mathrm{L} \mathrm{Mg}$; T2, drinking water $+4 \mathrm{mg} / \mathrm{L} \mathrm{Ca}+510 \mathrm{mg} / \mathrm{L} \mathrm{Mg} / 10 \mathrm{~L}$; and T3, drinking water + $5 \mathrm{mg} / \mathrm{L} \mathrm{Ca}$ and $760 \mathrm{mg} / \mathrm{L} \mathrm{Mg}$. The experimental diets followed the recommendations of the Hy-Line Brown handbook and were provided as mash (Table 1).

Table 1 Diet composition (as-fed basis) for Hy-line Brown laying hens

\begin{tabular}{llll}
\hline Ingredients & $\%$ & \multicolumn{2}{l}{ Analysed nutrient composition } \\
\hline Corn & 58.90 & ME, kcal/kg & 2,800 \\
Soybean meal & 27.22 & Crude protein, \% & 17.20 \\
Tallow & 2.822 & Fat, \% & 5.10 \\
Tricalcium phosphate & 1.84 & Calcium, \% & 3.9 \\
Limestone $^{1}$ & 8.04 & Total phosphorus, \% & 0.7 \\
Vitamin premix & Available phosphorus, \% & 0.45 \\
Mineral premix & & & \\
Salt & 0.12 & & \\
DL-methionine (50\%) & 0.10 & &
\end{tabular}

${ }^{1}$ Tricalcium phosphate contains $32 \%$ calcium and 18\% P phosphorus (National Research Council, 1994)

${ }^{2}$ Vitamin A: 125,000 IU, vitamin D3: 2,500 IU, vitamin E: $10 \mathrm{mg}$, vitamin K3: $2 \mathrm{mg}$, vitamin B1: $1 \mathrm{mg}$, vitamin B2: $5 \mathrm{mg}$, vitamin B6: $1 \mathrm{mg}$, vitamin B12: $15 \mathrm{mg}$, folic acid: $500 \mathrm{mg}$, niacin: 35,000 mg, Ca-Pantothenate: 10,000 mg, biotin: $50 \mathrm{mg}$ per $\mathrm{kg}$ of diet

${ }^{3}$ Manganese: $8 \mathrm{mg}$, zinc: $60 \mathrm{mg}$, copper: $25 \mathrm{mg}$, iron: $40 \mathrm{mg}$, cobalt: $0.3 \mathrm{mg}$, iodine: $1.5 \mathrm{mg}$

Egg production and rate of broken eggs were measured weekly, whereas water consumption was recorded daily. Egg quality was checked weekly throughout the trial. A total of 40 eggs with single yolks and had shells that were free of visual defects and cracked shells were collected randomly at $17 \mathrm{~h} 00$ per treatment ( 5 per replication, $n=40$ ) per week and were used to determine egg quality at $20 \mathrm{~h} 00$ on the same day. Egg weight, eggshell crack, yolk colour, yolk height, albumen height, and Haugh unit were tested with a digital egg tester (NABEL DET6000, Kyoto, Japan). Then eggshell thicknesses of the broader end, equatorial region and the narrow end were calculated with an eggshell thickness gauge. Finally, 300 defectfree eggs were collected randomly at $17 \mathrm{~h} 00$ from each treatment. The eggs were stored in a refrigerated chamber $\left(4^{\circ} \mathrm{C}\right)$ and at room temperature $\left(20^{\circ} \mathrm{C}\right)$ for 0 (starting day), 1, 5, 10, and 15 days. Humidity was $55 \%$ to $60 \%$ for all treatments. The sampled eggs then were used to determine Haugh unit and albumen height at 20 h00 on days $0,1,5,10$, and 15 with a digital egg tester (NABEL, DET6000, Japan). All measurements were recorded each week to investigate the supplementation effects of $\mathrm{Ca}$ and $\mathrm{Mg}$ and to optimize the duration of supplementation. 
Data were analysed with a completely randomized design using mixed procedures of SAS (SAS Institute, Inc., Cary, North Carolina, USA) to quantify the linear and quadratic effects using polynomial regression. Effects with a probability level less than 0.05 were considered statistically significant, whereas $0.05 \leq P<0.10$ was regarded as indicating a trend.

\section{Results and Discussion}

There was a linear decrease $(P=0.04)$ in water intake in week 1 with increasing levels of mineral supplementation of the drinking water (Table 2). However, no significant $(P>0.05)$ change in water intake was observed with the addition of $\mathrm{Ca}$ and $\mathrm{Mg}$ in the subsequent weeks.

Table 2 Effects of supplementation of calcium and magnesium in drinking water on water intake in laying hens

\begin{tabular}{|c|c|c|c|c|c|c|c|}
\hline \multirow{2}{*}{ Week } & \multicolumn{4}{|c|}{ Treatments } & \multirow{2}{*}{ SE } & \multicolumn{2}{|c|}{$P$-value } \\
\hline & Control & $\mathrm{T} 1$ & $\mathrm{~T} 2$ & T3 & & Linear & Quadratic \\
\hline 1 & 203 & 201 & 201 & 199 & 1.17 & 0.04 & 0.92 \\
\hline 2 & 199 & 201 & 201 & 200 & 0.88 & 0.90 & 0.28 \\
\hline 3 & 199 & 199 & 199 & 198 & 1.07 & 0.51 & 0.32 \\
\hline 4 & 197 & 198 & 199 & 199 & 0.76 & 0.06 & 0.34 \\
\hline 5 & 201 & 198 & 199 & 198 & 1.18 & 0.32 & 0.54 \\
\hline 6 & 199 & 199 & 199 & 198 & 0,82 & 0,39 & 0,46 \\
\hline 7 & 199 & 199 & 199 & 198 & 0,82 & 0,39 & 0,46 \\
\hline
\end{tabular}

T1: 2 mg/L Ca + 250 mg/L Mg; T2: 4 mg/L Ca +510 mg/L Mg /10 L; T3: 5 mg/L Ca + 760 mg/L Mg

The effects of higher levels of $\mathrm{Ca}$ and $\mathrm{Mg}$ and other minerals in the water should be assessed to find a maximum tolerable level for hens, at which performance and egg quality are not affected (Table 3). Likewise, Akbar et al. (1983) noted no change in egg weight, eggshell thickness, or egg breaking strength when laying hens were provided drinking water that contained $625 \mathrm{ppm} \mathrm{MgSO}_{4}, 1250 \mathrm{ppm} \mathrm{MgSO}$, and $625 \mathrm{ppm} \mathrm{MgSO} 4$ plus $1417 \mathrm{ppm}$ calcium sulphate. The decreased rate of broken eggs in the current study was attributed to improved eggshell thickness and eggshell strength. 
Table 3 Effects of supplementation of calcium and magnesium in drinking water on egg production, rate of broken eggs, and egg weight in laying hens ${ }^{1}$

\begin{tabular}{|c|c|c|c|c|c|c|c|}
\hline & \multicolumn{4}{|c|}{ Treatments } & \multirow{2}{*}{ SE } & \multicolumn{2}{|c|}{$P$-value } \\
\hline & Control & $\mathrm{T} 1$ & $\mathrm{~T} 2$ & T3 & & Linear & Quadratic \\
\hline \multicolumn{8}{|c|}{ Egg production, \% } \\
\hline Week 1 & 85.0 & 85.4 & 85.6 & 85.9 & 1.80 & 0.72 & 0.97 \\
\hline Week 2 & 85.1 & 85.3 & 85.7 & 85.9 & 2.61 & 0.81 & 0.99 \\
\hline Week 3 & 85.0 & 85.4 & 85.6 & 85.7 & 1.36 & 0.64 & 0.87 \\
\hline Week 4 & 84.8 & 85.3 & 85.4 & 85.6 & 1.62 & 0.74 & 0.93 \\
\hline Week 5 & 84.5 & 85.0 & 85.4 & 85.7 & 1.94 & 0.65 & 0.97 \\
\hline Week 6 & 84.1 & 84.8 & 85.0 & 85.3 & 2.73 & 0.73 & 0.94 \\
\hline \multicolumn{8}{|c|}{ Broken egg rate, $\%$} \\
\hline Week 1 & 0 & 0.2 & 0.2 & 0.2 & 0.12 & 0.5 & 0.5 \\
\hline Week 2 & 0.3 & 0.0 & 0.2 & 0.2 & 0.25 & 0.63 & 0.29 \\
\hline Week 3 & 0.4 & 0.0 & 0.2 & 0.2 & 0.21 & 0.63 & 0.29 \\
\hline Week 4 & 0.5 & 0.0 & 0.0 & 0.0 & 0.12 & 0.00 & 0.01 \\
\hline Week 5 & 0.2 & 0.5 & 0.2 & 0.4 & 0.21 & 0.87 & 0.71 \\
\hline Week 6 & 0.3 & 0.2 & 0.3 & 0.0 & 0.35 & 0.47 & 0.74 \\
\hline \multicolumn{8}{|l|}{ Egg Weight } \\
\hline Start & 64.55 & 65.23 & 65.48 & 65.57 & 0.83 & 0.39 & 0.74 \\
\hline Week 1 & 65.18 & 65.34 & 65.31 & 65.48 & 0.98 & 0.84 & 0.99 \\
\hline Week 2 & 65.11 & 65.14 & 65.28 & 65.46 & 0.97 & 0.79 & 0.94 \\
\hline Week 3 & 64.79 & 65.03 & 65.11 & 65.37 & 1.06 & 0.69 & 0.99 \\
\hline Week 4 & 64.72 & 65.03 & 65.23 & 65.3 & 1.05 & 0.67 & 0.91 \\
\hline Week 5 & 65.04 & 65.15 & 65.29 & 65.38 & 1.04 & 0.8 & 0.99 \\
\hline Week 6 & 64.96 & 65.17 & 65.23 & 65.38 & 1.08 & 0.78 & 0.98 \\
\hline
\end{tabular}

${ }^{1}$ Values of means represent 8 replications per treatment and 12 birds per replication

T1: 2 mg/L Ca +250 mg/L Mg, T2: 4 mg/L Ca + 510 mg/L Mg /10 L, T3: 5 mg/L Ca + 760 mg/L Mg

No significant differences were noted in egg production, egg weight and internal egg quality (eggshell colour, Haugh unit, albumen height, and yolk colour) on the starting day and in weeks 1,2, 3, 4, 5, and 6 with increasing the $\mathrm{Ca}$ and $\mathrm{Mg}$ levels in the drinking water $(P>0.05)$ (Table 4). 
Table 4 Effect of supplementation of calcium and magnesium in drinking water on egg quality in laying hens ${ }^{1}$

\begin{tabular}{|c|c|c|c|c|c|c|c|}
\hline & \multicolumn{4}{|c|}{ Treatments } & \multirow{2}{*}{ SE } & \multicolumn{2}{|c|}{$P$-value } \\
\hline & Control & $\mathrm{T} 1$ & T2 & T3 & & Linear & Quadratic \\
\hline \multicolumn{8}{|l|}{ Shell colour } \\
\hline Start & 10.0 & 10.3 & 10.3 & 10.4 & 0.30 & 0.37 & 0.72 \\
\hline Week 1 & 10.1 & 10.3 & 10.4 & 10.4 & 0.26 & 0.37 & 0.80 \\
\hline Week 2 & 10.2 & 10.3 & 10.2 & 10.7 & 0.30 & 0.24 & 0.48 \\
\hline Week 3 & 10.4 & 10.2 & 10.7 & 10.8 & 0.30 & 0.27 & 0.62 \\
\hline Week 4 & 10.3 & 10.1 & 10.2 & 10.9 & 0.32 & 0.18 & 0.18 \\
\hline Week 5 & 10.4 & 10.0 & 10.6 & 10.6 & 0.29 & 0.37 & 0.39 \\
\hline Week 6 & 10.5 & 10.2 & 10.6 & 10.7 & 0.31 & 0.50 & 0.59 \\
\hline \multicolumn{8}{|c|}{ Eggshell strength, $\mathrm{kg} / \mathrm{cm}^{2}$} \\
\hline Start & 3.838 & 3.848 & 3.865 & 3.875 & 0.02 & 0.24 & 0.97 \\
\hline Week 1 & 3.812 & 3.833 & 3.876 & 3.884 & 0.03 & 0.06 & 0.82 \\
\hline Week 2 & 3.790 & 3.869 & 3.878 & 3.884 & 0.03 & 0.01 & 0.15 \\
\hline Week 3 & 3.792 & 3.818 & 3.827 & 3.833 & 0.03 & 0.23 & 0.69 \\
\hline Week 4 & 3.814 & 3.817 & 3.824 & 3.852 & 0.03 & 0.29 & 0.62 \\
\hline Week 5 & 3.769 & 3.816 & 3.836 & 3.858 & 0.03 & 0.01 & 0.63 \\
\hline Week 6 & 3.782 & 3.827 & 3.831 & 3.869 & 0.03 & 0.03 & 0.88 \\
\hline \multicolumn{8}{|c|}{ Eggshell thickness, mm } \\
\hline Start & 46.7 & 46.4 & 46.8 & 46.8 & 0.50 & 0.96 & 0.71 \\
\hline Week 1 & 46.9 & 46.9 & 46.6 & 46.5 & 0.49 & 0.43 & 1.00 \\
\hline Week 2 & 47.6 & 47.7 & 47.0 & 46.5 & 0.50 & 0.08 & 0.44 \\
\hline Week 3 & 45.9 & 46.2 & 46.7 & 46.8 & 0.50 & 0.17 & 0.82 \\
\hline Week 4 & 46.2 & 46.4 & 46.4 & 46.7 & 0.50 & 0.64 & 0.85 \\
\hline Week 5 & 46.3 & 46.6 & 46.8 & 46.9 & 0.51 & 0.35 & 0.87 \\
\hline Week 6 & 45.4 & 46.4 & 46.7 & 47.3 & 0.5 & 0.02 & 0.60 \\
\hline
\end{tabular}

${ }^{1}$ Values of means represent 8 replications per treatment and 12 birds per replication

$\mathrm{T} 1: 2 \mathrm{mg} / \mathrm{L} \mathrm{Ca}+250 \mathrm{mg} / \mathrm{L} \mathrm{Mg}$, T2: $4 \mathrm{mg} / \mathrm{L} \mathrm{Ca}+510 \mathrm{mg} / \mathrm{L} \mathrm{Mg} / 10 \mathrm{~L}, \mathrm{~T} 3: 5 \mathrm{mg} / \mathrm{L} \mathrm{Ca}+760 \mathrm{mg} / \mathrm{L} \mathrm{Mg}$

Minerals in drinking water can change the quality of the eggshell. A number of studies found a harmful influence on eggshell quality (West et al., 1980; Wang et al., 2020) of high levels of sodium chloride ( $\mathrm{NaCl}$ ) in drinking water, but studies on the effects of minerals such as $\mathrm{Ca}$ and $\mathrm{Mg}$ in water on hen performance and egg quality are limited. In addition, results of studies of high levels of minerals in the diet or water for laying hens have differed. For example, Kim et al. (2013) found that the addition of $500 \mathrm{mg} / \mathrm{kg} \mathrm{Mg}$ to the diet for laying hens was sufficient to improve eggshell thickness and subsequently reduce the proportion of breakages. Supplementation of $\mathrm{Mg}$ above $5 \mathrm{~g} / \mathrm{kg}$, at $4.7 \mathrm{~g} / \mathrm{kg}$, and at $3 \mathrm{~g} / \mathrm{kg}$ increased the eggshell quality in laying hens (National Research Council 1994), but an excessive amount (2380 mg/kg) did not have a disadvantageous effect on egg production. In addition, Stilborn et al. (1989) suggested that the addition of $2500 \mathrm{mg} / \mathrm{kg} \mathrm{Mg}$ to the practical diet for layers did not improve their eggshell quality (Ahn et al., 1997).

However, adding treatments of $\mathrm{Ca}$ and $\mathrm{Mg}$ to the drinking water raised eggshell strength linearly (weeks 2,5 , and 6) $(P=0.01,0.01,0.03$, respectively), increased eggshell thickness (week 6) $(P=0.02)$, and decreased the broken egg rate quadratically (week 4) $(P=0.01)$ (Table 5). 
Table 5 Effect of supplementation of calcium and magnesium to drinking water for laying hens on interior egg quality ${ }^{1}$

\begin{tabular}{|c|c|c|c|c|c|c|c|}
\hline & \multicolumn{4}{|c|}{ Treatments } & \multirow{2}{*}{ SEM } & \multicolumn{2}{|c|}{ P-value } \\
\hline & $\mathrm{CON}$ & $\mathrm{T} 1$ & T2 & T3 & & Linear & Quadratic \\
\hline \multicolumn{8}{|l|}{ Haugh Unit } \\
\hline Start & 90.3 & 90.5 & 90.7 & 90.9 & 0.78 & 0.57 & 0.99 \\
\hline Week 1 & 90.2 & 90.4 & 90.8 & 91.5 & 0.91 & 0.29 & 0.73 \\
\hline Week 2 & 90.3 & 90.8 & 90.8 & 91.6 & 0,95 & 0.38 & 0.88 \\
\hline Week 3 & 89.4 & 90.3 & 90.3 & 91.3 & 1.35 & 0.35 & 0.98 \\
\hline Week 4 & 89.7 & 90.0 & 90.6 & 91.7 & 1.3 & 0.28 & 0.74 \\
\hline Week 5 & 89.4 & 90.8 & 91.4 & 91.7 & 1.34 & 0.22 & 0.68 \\
\hline Week 6 & 89.0 & 90.2 & 90.5 & 91.0 & 1.37 & 0.31 & 0.79 \\
\hline \multicolumn{8}{|c|}{ Albumen height, mm } \\
\hline Start & 8.2 & 8.4 & 8.5 & 8.4 & 0.21 & 0.39 & 0.71 \\
\hline Week 1 & 7.9 & 8.3 & 8.5 & 8.4 & 0.21 & 0.07 & 0.18 \\
\hline Week 2 & 8.3 & 8.2 & 8.0 & 8.1 & 0.24 & 0.43 & 0.57 \\
\hline Week 3 & 8.3 & 8.5 & 8.5 & 8.7 & 0.24 & 0.25 & 0.95 \\
\hline Week 4 & 8.3 & 8.4 & 8.5 & 8.8 & 0.25 & 0.20 & 0,77 \\
\hline Week 5 & 8.3 & 8.5 & 8.7 & 8.8 & 0.24 & 0.15 & 0.63 \\
\hline Week 6 & 8.2 & 8.4 & 8.6 & 8.6 & 0.24 & 0.24 & 0.75 \\
\hline \multicolumn{8}{|l|}{ Yolk colour } \\
\hline Start & 8.2 & 8.2 & 8.4 & 8.2 & 0.26 & 0.89 & 0.65 \\
\hline Week 1 & 8.3 & 8.4 & 8.2 & 8.6 & 0.28 & 0.55 & 0.72 \\
\hline Week 2 & 8.2 & 8.3 & 8.3 & 8.1 & 0.26 & 0.82 & 0.53 \\
\hline Week 3 & 7.9 & 8.4 & 8.6 & 8.2 & 0.36 & 0.41 & 0.2 \\
\hline Week 4 & 7.7 & 8.4 & 8.1 & 8.0 & 0.36 & 0.72 & 0.29 \\
\hline Week 5 & 8.0 & 8.0 & 8.3 & 8.0 & 0.35 & 0.83 & 0.77 \\
\hline Week 6 & 7.9 & 7.8 & 8.1 & 8.2 & 0.37 & 0.43 & 0.82 \\
\hline
\end{tabular}

${ }^{\top}$ Values of means represent 8 replications per treatment and 12 birds per replication

$\mathrm{T} 1: 2 \mathrm{mg} / \mathrm{L} \mathrm{Ca}+250 \mathrm{mg} / \mathrm{L} \mathrm{Mg}$, T2: $4 \mathrm{mg} / \mathrm{L} \mathrm{Ca}+510 \mathrm{mg} / \mathrm{L} \mathrm{Mg} / 10 \mathrm{~L}$, T3: $5 \mathrm{mg} / \mathrm{L} \mathrm{Ca}+760 \mathrm{mg} / \mathrm{L} \mathrm{Mg}$

Haugh unit and albumen height were not affected by increasing the concentration of the $\mathrm{Ca}$ and $\mathrm{Mg}$ in the drinking water $(P>0.05)$ after storing the eggs for $1,5,10$, and 15 days (Table 6$)$.

Eggs contain high biological value protein and essential minerals (Hawley et al., 1946). The diet that is provided to laying hens has a crucial effect on the quality of eggs (Kowalska et al., 2021). The quality of water influences the quality of eggs, even if a balanced diet is provided (Damron \& Flunker, 1995). Although water does not supply energy, it is necessary for various metabolic functions. Increased levels of minerals can be undesirable to birds, and reduce performance (Yoselewitz et al., 2008). In agreement with the current results, Yoselewitz et al. (2012) reported that water consumption was lower at 625, 1250, and $1417 \mathrm{ppm}$ magnesium sulfate (MgSO4) than that of control. Pourreza et al. (1994) found a parallel effect of high $\mathrm{MgSO}_{4}$ in the drinking water on its consumption of laying hens. In addition, Sus and Balnave (1975) found that daily water consumption was significantly lower when Ca was supplied at $3.5 \%$ and $2.5 \%$ in the diet and at $0.2 \%$ in the drinking water. The decrease in water intake in the first week of experiment could be because of the change in taste when $\mathrm{Ca}$ and $\mathrm{Mg}$ were added. However, after the first week, laying hens might adapt to the change. No significant impact was noticed in continued weeks (Table 2). 
Table 6 Effect on Haugh unit and albumen height ${ }^{1}$ of supplementation of calcium and magnesium in drinking water for laying hens

\begin{tabular}{|c|c|c|c|c|c|c|c|}
\hline & \multicolumn{4}{|c|}{ Treatments } & \multirow{2}{*}{ SE } & \multicolumn{2}{|c|}{$P$-value } \\
\hline & Control & $\mathrm{T} 1$ & $\mathrm{~T} 2$ & T3 & & Linear & Quadratic \\
\hline \multicolumn{8}{|l|}{ Haugh Unit } \\
\hline Start & 89.60 & 90.25 & 90.67 & 92.32 & 2.25 & 0.41 & 0.83 \\
\hline Day 1 & 88.27 & 89.42 & 90.57 & 91.48 & 2.34 & 0.31 & 0.93 \\
\hline Day 5 & 87.53 & 88.03 & 88.58 & 90.58 & 2.49 & 0.39 & 0.77 \\
\hline Day 10 & 83.20 & 84.45 & 84.70 & 85.80 & 1.24 & 0.16 & 0.95 \\
\hline Day 15 & 80.83 & 81.27 & 82.33 & 83.63 & 0.88 & 0.27 & 0.63 \\
\hline \multicolumn{8}{|c|}{ Albumen height, mm } \\
\hline Start & 8.13 & 8.23 & 8.28 & 9.38 & 0.33 & 0.02 & 0.15 \\
\hline Day 1 & 7.75 & 8.58 & 8.75 & 8.40 & 0.50 & 0.35 & 0.25 \\
\hline Day 5 & 7.93 & 8.22 & 8.48 & 8.63 & 0.42 & 0.22 & 0.88 \\
\hline Day 10 & 7.97 & 8.13 & 8.37 & 8.43 & 0.29 & 0.22 & 0.86 \\
\hline Day 15 & 7.82 & 8.07 & 8.15 & 8.25 & 0.46 & 0.56 & 0.91 \\
\hline
\end{tabular}

${ }^{\top}$ Values of means represent 8 replications per treatment and 12 birds per replication

$\mathrm{T} 1: 2 \mathrm{mg} / \mathrm{L} \mathrm{Ca}+250 \mathrm{mg} / \mathrm{L} \mathrm{Mg}$, T2: $4 \mathrm{mg} / \mathrm{L} \mathrm{Ca}+510 \mathrm{mg} / \mathrm{L} \mathrm{Mg} / 10 \mathrm{~L}, \mathrm{~T} 3: 5 \mathrm{mg} / \mathrm{L} \mathrm{Ca}+760 \mathrm{mg} / \mathrm{L} \mathrm{Mg}$

Albumen height, albumen percentage and yolk percentage were not affected when laying hens were provided drinking water with $625 \mathrm{ppm} \mathrm{MgSO}_{4}, 1250 \mathrm{ppm} \mathrm{MgSO}_{4}$, and $625 \mathrm{ppm} \mathrm{MgSO}$ plus $1417 \mathrm{ppm}$ calcium sulphate in the study of Akbar et al. (1983). According to Keener et al. (2006), the Haugh unit is a measure of albumen quality and therefore of the freshness of the egg, whereas Silversides et al. (1993) proposed that albumen height should be measured to determine egg quality. Various factors affect Haugh units, including storage time, temperature, age of hen, strain, and nutrition (Lapao et al., 1999). Temperature and storage time appear to be crucial factors that affect albumen quality and Haugh unit (Jones et al., 2001). Eggshell thickness was related negatively to eggshell water conductance (Samli et al., 2005).

\section{Conclusion}

The addition of up to $5 \mathrm{mg} / \mathrm{L} \mathrm{Ca}$ and $760 \mathrm{mg} / \mathrm{L} \mathrm{Mg} \mathrm{(T3)} \mathrm{to} \mathrm{the} \mathrm{drinking} \mathrm{water} \mathrm{improved} \mathrm{eggshell}$ thickness and eggshell strength without unfavourable consequences to egg quality and egg production of laying hens.

\section{Acknowledgements}

The first author acknowledges the financial grant from Ningxia University (Ningxia Xiaoming Agriculture and Husbandry Co., Ltd.), Yinchuan, Ningxia, China.

\section{Authors' Contributions}

XJY, AR and HSH conceived and designed the experiments. XJY, AR, RY and RWA analysed the data and drafted the manuscript. YNG, AR, HMl and HSH performed experiments and acquired data. YNG, RZA, KH, MAR and AR revised the manuscript. All authors read and approved the final manuscript.

\section{Conflict of Interest Declaration}

There is no conflict of interest for this study.

\section{References}

Adams, A.W., Cunningham, F.E. \& Munger, L.L., 1975. Some effects on layers of sodium sulfate and magnesium sulfate in their drinking water. Poult. Sci. 54, 707-714. https://doi.org/10.3382/ps.0540707

Ahn, D.U, Kim, S.M. \& Shu, H. 1997. Effect of egg size and strain and age of hens on the solids content of chicken eggs. Poult. Sci. 76, 914-919. DOI: 10.1093/ps/76.6.914

Akbar, M.K., Gavora, J.S. Friars G.W. \& Gowe, R.S., 1983. Composition of eggs by commercial size categories: Effects of genetic group, age, and diet. Poult. Sci. 62, 925-933. https://doi.org/10.3382/ps.0620925 
Ariyamuni, D., 2015. Evaluation of pH levels or high content of calcium, magnesium and sulphate in drinking water on production performance, egg quality, bone quality and mineral retention of laying hens. Master of Science thesis, Dalhousie University, Halifax, Nova Scotia.

Blake, J.P., Hess, J.B. \& Maklin, K.S., 2019. Evaluating water quality for poultry. Alabama Cooperative Extension System. https://www.aces.edu/blog/topics/farming/evaluating-water-quality-for-poultry/

Chung, E.L.T., Nayan, N., Kamalludin, M.H., Alghirani, M.M., Jesse, F.F.A., Kassim, N.A., Azizi, A., Reduan, M.F.H. \& Loh, T.C., 2020. The effects of alkaline water and rainwater on the production and health performance of commercial broilers under tropical conditions. Thai J. Vet. Med. 50(1), 65-73.

Cufadar, Y., Olgun, O. \& Yildiz, A.Ö., 2011. The effect of dietary calcium concentration and particle size on performance, eggshell quality, bone mechanical properties and tibia mineral contents in moulted laying hens. British Poultry Science, 52(6), 761-768. DOI: 10.1080/00071668.2011.641502

Damron, B.L. \& Flunker, LK., 1995. Calcium supplementation of hen drinking water. Poult. Sci. 74, $784-787$. https://doi.org/10.3382/ps. 0740784

Hawley, E.E., Edwards, L.E., Clark, L.C., Murlin, J.R. \& Morabitoet, A., 1946. Biological value of proteins in relation to the essential amino acids which they contain. V. Comparison of the average effect of ten single amino acids with extra egg protein as supplements to an egg diet. J. Nutr. 32(6), 613-630. DOI: 10.1093/jn/32.6.613

Jones, D.R., Anderson, K.E. \& Davis, G.S. 2001. The effects of genetic selection on production parameters of single comb White Leghorn hens. Poult. Sci. 80, 1139-1143. DOI: 10.1093/ps/80.8.1139

Keener, K.M., McAvoy, K.C., Foegeding, J.B., Curtis, P.A., Anderson, K.E. \& Osborne, J.A., 2006. Effect of testing temperature on internal egg quality measurements. Poult. Sci. 85, 550-555. DOI: 10.1093/ps/85.3.550

Kim, C.H., Paik, I.K. \& Kil, D.Y., 2012. Effects of increasing supplementation of magnesium in diets on productive performance and eggshell quality of aged laying hens. Biol. Trace. Elem. Res. 151, 38-42. DOI: 10.1007/s12011012-9537-z

Kowalska, E., Kucharska-Gaca, J., Kuźniacka, J., Lewko, L., Gornowicz, E., Biesek, J. \& Adamski, M., 2021. Egg quality depending on the diet with different sources of protein and age of the hens. Sci. Rep. 11, 2638. https://doi.org/10.1038/s41598-021-82313-1

Lapao, C., Gama, L.T. \& Soares, M.C., 1999. Effects of broiler breeder age and length of egg storage on albumen characteristics and hatchability. Poult. Sci. 78, 640-645. DOI: 10.1093/ps/78.5.640

Leeson, S. \& Summers, J.D., 2008. Commercial poultry nutrition. 3rd revised edition. Nottingham University Press, England.

National Research Council, 1994. Nutrient requirements of poultry. Ninth revised edition. National Academy of Science, Washington DC.

Peebles, E.D. \& Brake, J., 1987. Eggshell quality and hatchability in broiler breeder eggs. Poult. Sci. 66, 596-604. https://doi.org/10.3382/ps.0660596

Pourreza, J., Nili, N. \& Edriss, M.A., 1994. Relationship of plasma calcium and phosphorus to the shell quality of laying hens receiving saline drinking water. Br. Poult. Sci. 35,755-762. https://doi.org/10.1080/00071669408417740

Roberts, J.R., 2004. Factors affecting egg internal quality and egg shell quality in laying hens. J. Poult. Sci. 41, $161-177$. https://doi.org/10.2141/jpsa.41.161

Samli, H.E., Agma, A. \& Senkoylu, N., 2005. Effects of storage time and temperature on egg quality in old laying hens. J. Appl. Poult. Res. 14, 548-553. https://doi.org/10.1093/japr/14.3.548

Schlink, A.C., Nguyen, M.L. \& Viljoen, G.J., 2010. Water requirements for livestock production: A global perspective. Rev. Sci. Tech. 29, 603-619. DOI: 10.20506/rst.29.3.1999

Silversides, F.G., Twizeyimana, F. \& Villeneuve, P., 1993. Research note: A study relating to the validity of the Haugh unit correction for egg weight in fresh eggs. Poult. Sci. 72, 760-764. https://doi.org/10.3382/ps.0720760

Stilborn, H.L., Hellwig, H.M. \& Waldroup, P.W., 1989. Effects of supplemental magnesium in diets of laying hens on egg production and egg quality parameters. Nutr. Rep. Int. 40,123-128.

Sus, H. \& Balnave, D., 1975. Magnesium zusatz bei legehennen. Arch. Gefluglek. 39, 99-102.

Wang, J., Zhang, H.J., Wu, S.G., Qi, G.H. \& Xu, L., 2020. Dietary chloride levels affect performance and eggshell quality of laying hens by substitution of sodium sulfate for sodium chloride. Poult. Sci. 99(2), 966-973. https://doi.org/10.1016/j.psj.2019.10.030

West, B.L., Williams, P.L., Nockels, C.F. \& Enos, H.L., 1980. Calcium, magnesium and phosphorus for aging hens. Poult. Sci. 59, 1672 (abstract).

Whitehead, C.C., 2004. Overview of bone biology in the egg-laying hen. Poult. Sci. 83, 193-199. https://doi.org/10.1093/ps/83.2.193

Yenice, E., Mızrak, C., Gültekin, M., Atik, Z. \& Tunca, M., 2015. Effects of organic and inorganic forms of manganese, zinc, copper, and chromium on bioavailability of these minerals and calcium in late-phase laying hens. Biol. Trace Elem. Res. 167(2), 300-307. DOI: 10.1007/s12011-015-0313-8

Yoselewitz, I. \& Balnave, D., 1989. The influence of saline drinking water on the activity of carbonic anhydrase in the shell gland of laying hens. Aust. J. Agric. Res. 40, 111-115. https://doi.org/10.1071/AR9891111

Yoselewitz, I. \& Balnave, D., 1989. Egg shell quality responses of pullets given saline drinking water at different ages. Br. Poult. Sci. 30, 715-718. https://doi.org/10.1080/00071668908417195

Yoselewitz, I., Balnave, D. \& Dixon, R.J., 1988. Factors influencing the production of defective egg shells by laying hens receiving sodium chloride in the drinking water. Nutr. Rep. Int., 38, 697-703.

Youssef, M.Y., Mahmoud, A.K. \& Ali, H., 2009. Impact of drinking water quality on performance of a heavy turkey breed. Egypt. J. Comp. Path. \& Clinic. Path. 22, 109-128 (abstract) 